( J. Soc. Cosmet, Chem. Jpn.

$\left[\begin{array}{lll}\text { 報 } & \text { 文 } \\ 28(3) & 254-261 & (1994)\end{array}\right]$

\title{
無機粉体の紫外線防御機構
}

\author{
城倉博子，東 清史，鈴木敏幸，芋川玄爾 \\ 花王株式会社 生物科学研究所†
}

\section{Efficacy of Opaque Photoprotective Agents in UVA Range}

\author{
Joukura Hiroko, Higashi Kiyosi, Suzuki Toshiyuki and Imokawa Genji \\ Kao Biological Science Laboratories. $\uparrow$
}

\begin{abstract}
Opaque physical sunscreens, ie, those containing $\mathrm{TiO}_{2}$ (titanium dioxide) or $\mathrm{ZnO}$ (zinc oxide) are important for photoprotection in UVA range. However, little is known about relationship different shapes or sphere size and UVA protection efficacy. Therefore, we studied the UVA protective properties of $\mathrm{TiO}_{2}$ and $\mathrm{ZnO}$ with different shapes.

Absorption spectrum of dipersed materials showed that zinc oxides have a definite absorption peak at the range between 300 and $400 \mathrm{~nm}$, with the intensity observed in the order of flake> needle $>$ bead in their shapes.

In proportion to spectral characteristics, Zinc oxides exhibited a high UVA protective capacity as measured by guinea pig PUVA method with a similar order of shapes in their intensity.

UVA protection capacity with flake zinc oxide for human skin revealed a dose-dependent increase which was well correlated with relative transmission at the UVArange when applied to epidermal sheet.

Flake zinc oxide also showed the most suitable balance for having higher UVA protective capacity and lower whity effect.
\end{abstract}

\section{1. 緒言}

現在，化粧品に使用されている紫外線防御剤に は有機系の紫外線吸収剂之無機系の金属酸化物で ある紫外線散乱剂に大別される。現在める有機系 紫外線吸収剂は透明でクリーム系に配合しやすい ものであるが, 持続性, 安定性, 使用感 (ベたつ き感）に問題があり，末たUVA〜UVB の全領 域を一つの吸収剤でカバーできるものではない。

一方, 酸化亚鉛, 酸化チタンに代表される無機 系の金属酸化物は安全性が高く, 光安定性が優れ

$\dagger \overline{\mathbf{T}} 321-34$ 㭛木県芳賀郡市貝町赤羽 $2606 ； 2606$ Akabane Ichikai-machi, Haga-gun Tochigi 321-34 Japan
て扔り，UVA〜UVB 域を比較的広くカバーで きるものであるが，隠ぺい力があるため透明性が 低く，使用時に肌に白く残る現象『白浮き』や 『きしみ感』が生じる原因となる。そのため透明 性が要求されるクリーム，ミルクタイプなどには 大量の配合が困難となる。このように無機粉体を 化粧品に配合する場合に外観と使用感が問題とな

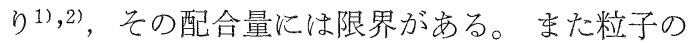
形状と紫外線防御効果については報告の例がな w。

そこで今回，我々は同じ金属酸化物であって も, その形状や粒径が紫外線防御効果や『白浮 き』度に影響することを確認した。その中で当社 が開発した薄片状酸化亜鉛は比較的透明性や紫外 
線防御效果が比較的高いもので, その PFA, PFB 值並びに，その配合クリームでの透明感（白浮さ の程度）について，形状の異なる酸化亚鉛と微粒 子酸化チタンと比較検討した絬果を以下で報告す る。

\section{2. 要旨}

粒状，針状，薄片状の形状が異なる酸化雨鈶の 吸収曲線を測定すると 300 400 nm 域に吸收を有 し，その大ささは薄片状〉釗状〉粒状で，動物を 用いた PUVA 法による PFA 值の評価結果とも 相関するものであった。また，酸化チタンでは結 晶の径が $0.2 \mu \mathrm{m} ， 0.05 \mu \mathrm{m}$ の吸収曲線を測定する と微粒子のものが $336 \mathrm{~nm}$ にピークK認め, より 紫外線防御効果が高いものであった。薄片状酸化 西鉛に和いてヒト背部での UVA 防御效果学測定 した結果，配合濃度の增加に伴い防御効果は高ま り，表皮シートを用いたUVA 域での透過度の湘 定結果と相関するものであった。さらに藻片状酸 化亜鉛は針状, 粒状のものと此較して UVA 防御 力が高く，比較的「白浮き」感が少ないサンスク リーン剂として配合しやすい紫外線散乱・吸収剤 であることが示唆された。

\section{3. 方法}

\section{1 試料}

酸化画鉛は形状が粒状 $(\phi 0.1 \mu \mathrm{m})$, 針状 $(\phi 0.1$ $\mu \mathrm{m})$ ，薄片状 $(\phi 0.3 \mu \mathrm{m})$ で結晶表面が未処理の

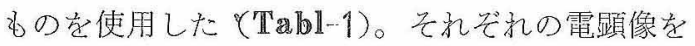
Fig:-1 飞示した。

Table-1 Sunscreen Preparation

\begin{tabular}{|c|c|c|}
\hline Form & Size & Treatment of Surface \\
\hline \multicolumn{3}{|c|}{ Titanium Dioxide $\left(\mathrm{TiO}_{2}\right)$} \\
\hline bead & $\theta 0.05 \mu \mathrm{m}$ & Silicone coated \\
\hline bead & $\theta 0.2 \mu \mathrm{m}$ & Silicone coated \\
\hline bead & $\theta 0.2 \mu \mathrm{m}$ & non-coated \\
\hline \multicolumn{3}{|c|}{ Zinc Oxide $(\mathrm{ZnO})$} \\
\hline flake & $\theta 0.3 \mu \mathrm{m}$ & Silicone coated \\
\hline needle & $00.1 \mu \mathrm{m}$ & non-coated \\
\hline bead & $\theta 0.1 \mu \mathrm{m}$ & non-coated \\
\hline
\end{tabular}
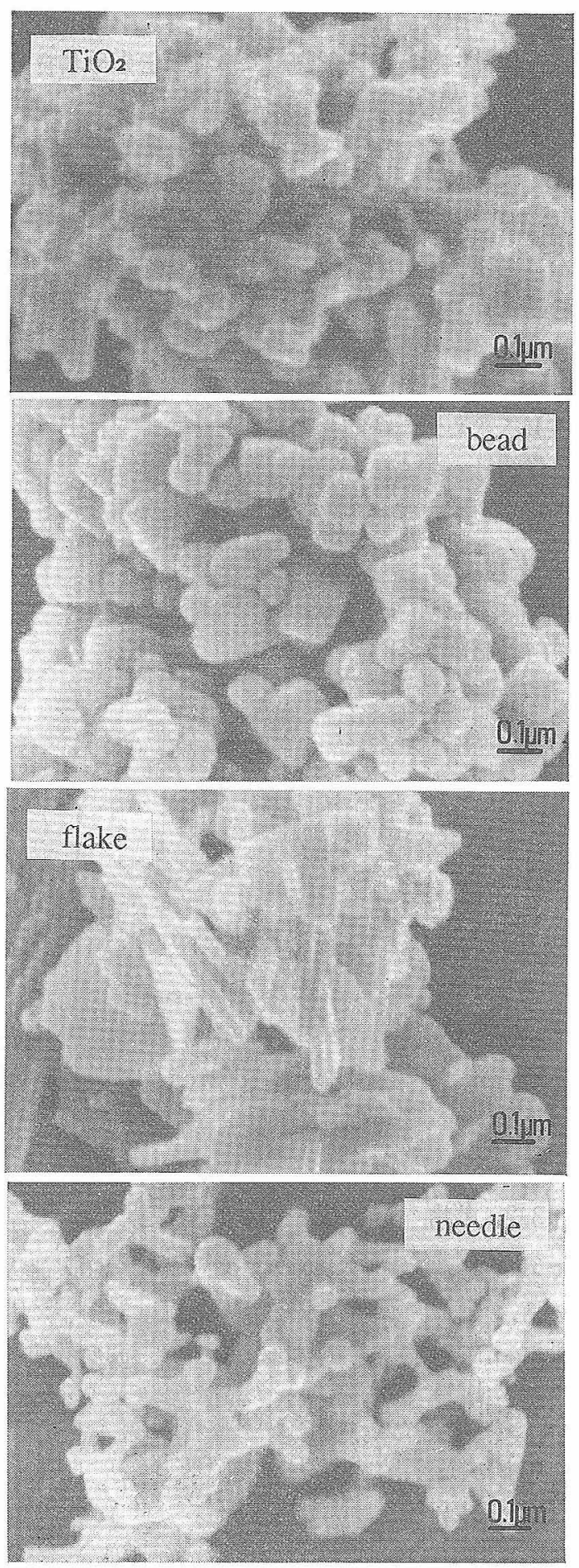

Fig.-1 Electron microscopic observation of $\mathrm{ZnO}$ (-bead, -needle, -flake) and $\mathrm{TiO} 2(\theta=0.05 \mu \mathrm{m})$. 
尚，薄片状酸化亜鉛は亜鉛イオンを含有し，そ れの当量を超える 1 種皇たは 2 種以上の酸基を含 有, かつ pH11 以上の亜鉛の塩を含む母液から沈 殿を生成させることにより製造されだ〉,4)。また， 酸化チタンは $\phi 0.05 \mu \mathrm{m}$ の微粒子で, 結晶面をシ リコン処理したもの， $\phi 0.2 \mu \mathrm{m}$ でシリコン処理し たものと末処理の 3 点を用いた。

ここでいう径 $(\phi)$ とは Fig.-2 示すように互 いに直交する 3 軸方向の最大值をL (Length), $\mathrm{B}$ (Breadth), $\mathrm{T}$ (Thickness) としLの平均を $\phi$ として求めた。各酸化亜鉛と酸化チタンは $\mathrm{EtOH}$ 分散溶液, 和よび $\mathrm{W} / \mathrm{O}$ 系クリーム(スクワラン, メチルポリシロキサン他配合）として用いた。
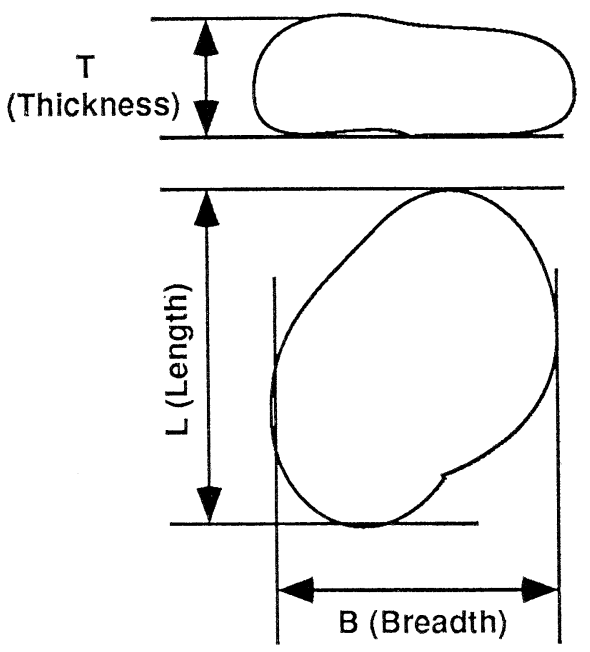

Fig.-2 粒径の求め方

\section{2 動物}

ハートレー系白色モルモット（体重 $250 \mathrm{~g}$ 前後 の吉, 4 週令) を恒温, 恒湿 $\left(22^{\circ} \mathrm{C}, 55 \%\right.$ 下で固 型試料, 水道水を自由摂取させて 2 週間の予備飼 育後, 実験に供した。

\section{4. 方法}

\section{1 紫外線防御効果の測定}

\subsubsection{PUVA 法5)}

㷙毛した白色モルモット背部に0.6\% 8-methoxy psoralen (Lot. GBO1) MARK 社の Et
$\mathrm{OH}$ 溶液を照射15分前に塗布し，アルミ製光遮断 シートで 8 分割し固定する。サンプル塗布（溶液 の場合 $2 \mu 1 / \mathrm{cm}^{2}$ クリームの場合 $2 \mathrm{mg} / \mathrm{cm}^{2}$ ) 後, 東芝 FL20-BLB1amp (365nmピーク) $3.1 \mathrm{~mW}$ $/ \mathrm{cm}^{2}$ で照射した $\left(0.9 \sim 6.5 \mathrm{~J} / \mathrm{cm}^{2} 1 \mathrm{MED}=0.9 \mathrm{~J} /\right.$ $\left.\mathrm{cm}^{2}\right)$ 。照射終了 48 時間後の最小紅斑量を日本皮膚 科学会基準に基づき判定し, PFA 值 (Protection Factor UVA) を求めた。

\subsubsection{UVB 法5)}

剃毛した白色モルモット背部をアルミ製光遮断 シートで 8 分割し固定する。サンプル塗布後, 東 芝 FL20SE1amp (305nm ピーク) $0.41 \mathrm{~mW} / \mathrm{cm}^{2}$ で照射した。照射終了 24 時間後の MEDを判定 し, PFB 值 (Protection Factor UVB) を求 めた。

\subsubsection{HEUVA (High energy UVA) 法} 健常人男性（平均年齢 $28 才, ~ n=8$ ) の背部にサ ンプルを $2 \mathrm{mg} / \mathrm{cm}^{2}$ 塗布し，その後超高圧水銀ラ ンプ $60 \mathrm{~mW} / \mathrm{cm}^{2}$ で照射し, 照射終了直後, 1 時 間後，24時間後の最小黒化量 (MMD : Minimal Meranogenic Dose) を判定し PFA 值とした $\left(1 \mathrm{MMD}=29.5 \pm 5.5 \mathrm{~J} / \mathrm{cm}^{2}\right)$

\section{2 透集度の測定}

\subsection{1 表皮シート}

剃毛した白色モルモットの背部皮膚を剥離し, $59 \sim 60^{\circ} \mathrm{C}$ の温水に $45 \sim 60$ 秒浸漬後, 直だちに氷 冷水に浸漬した。実体顕微鏡下で表皮と真皮を分 離し乾燥させ表皮シートとした。

\section{2 .2 透過度の測定}

$\mathrm{EtOH}$ 溶液の場合は薄片状酸化亚鉛の濃度 2.5 $\times 10^{-9} \%(\mathrm{~W} / \mathrm{V})$ の分散液を調製し，300 $50.0 \mathrm{~nm}$ の透過度 $(\% \mathrm{~T})$ を分光光度計で測定した。また表 皮シートを用いた場合は角層側にサンプル塗布 （溶液の場合 $2 \mu \mathrm{l} / \mathrm{cm}^{2}$, クリームの場合 $2 \mathrm{mg} / \mathrm{cm}^{2}$ ) し，15分後 2 枚の石英セルに㣣み $300 \sim 500 \mathrm{~nm}$ の 透過度（\%T）を測定した。

\section{3 白度の測定}

形状の異なる酸化亜 鉛を $(0.5,1 ， 2 ， 3 ， 5$, $10 \%$ ）配合したクリームを $2 \mathrm{mg}$ 塗布し 15 分経過 後, スライドガラスを挾み日本電色工業秼製色差 計にて $\Delta \mathrm{L}$ 值を測定した。 


\section{5. 結果及び考察}

\section{1 吸収曲線}

粒状，針状，薄片片酸化亜鉛それぞれ0.0025\% よび径と表面処理が異なる酸化チタン $0.00025 \%$ の $\mathrm{EtOH}$ 分散溶液の吸収曲線（200～500nm）を 測定した。

その結果，酸化亜鉛はいずれの形状に招いても

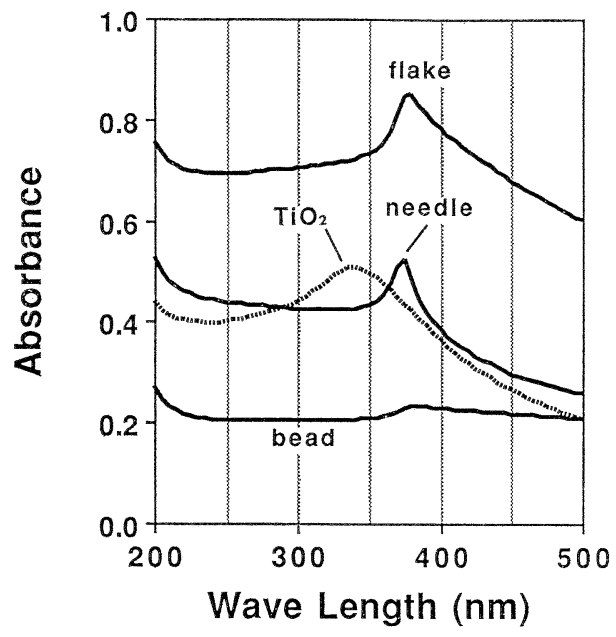

Fig.-3(a) Absorption spectrum of flake-, needle and bead- $\mathrm{ZnO}$ and $\mathrm{TiO} 2$ (Ultra fine).

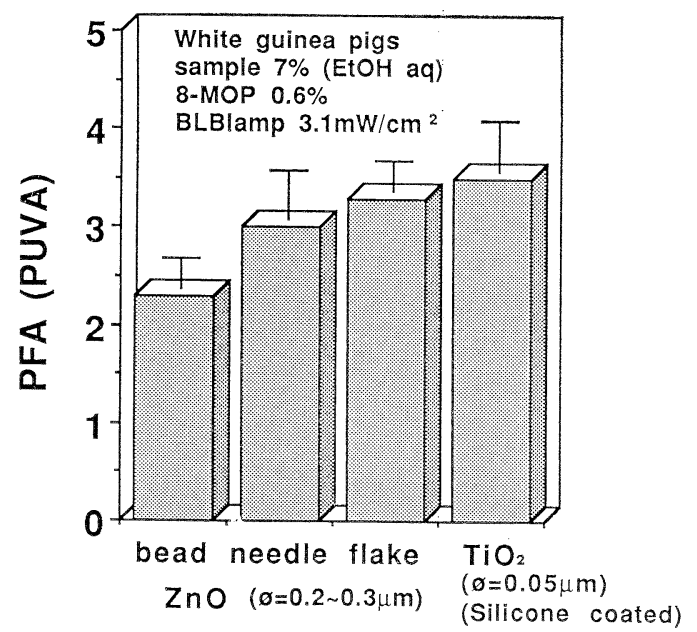

Fig. -3(b) Preventive effect of $\mathrm{ZnO}$ on PUVA-induced erythema in guinea pig skin. 365nmに吸収ピークをもつが，その吸収の大きさ は薄片状>針状>粒状の順であった（Fig-3(a)）。 このことは形状により散乱，吸収率が異なるため と考光られる。李た酸化チタンは径が $0.05 \mu \mathrm{m} の$ 微粒子の場合のみ $336 \mathrm{~nm}$ に吸収ピークを認め, さらに $400 \mathrm{~nm}$ 以上では $\phi 0.05 \mu \mathrm{m}$ の酸 化チタン は $\phi 0.2 \mu \mathrm{m}$ のものより吸収が小さくなることか ら径が小さい程，透明性が高いことが示唆された

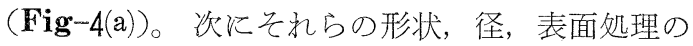
違いが紫外線防御効果の影響について検討を行っ た。

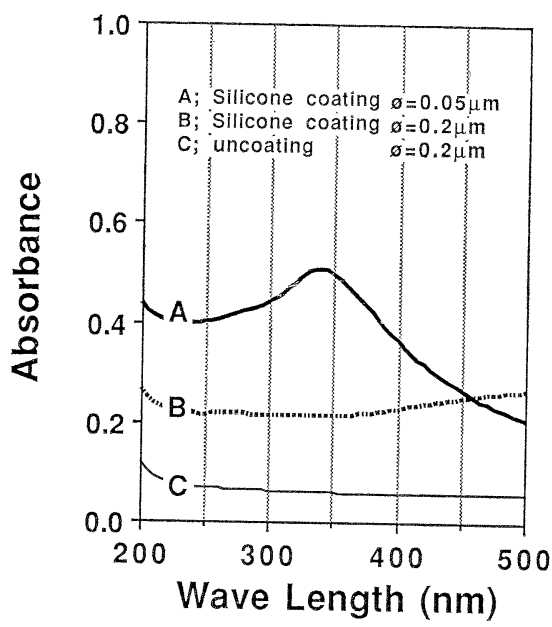

Fig. $-4($ a) Absorption spectrum of $\mathrm{TiO}$

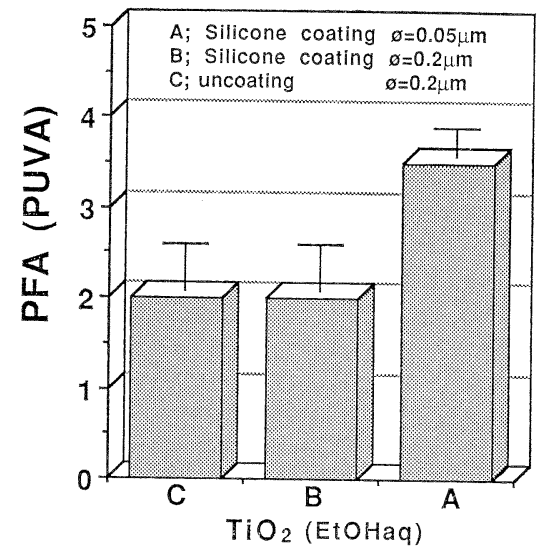

Fig. -4(b) Preventive effect of $\mathrm{TiO} 2$ on PUVA-induced erythema in guinea pig skin. 


\subsection{UVA 防御効果}

粒状，針状，薄片状酸化亜鉛，酸化チタンのそ れぞれ 7\% EtOH 分散溶液をPUVA 法にて PF $\mathrm{A}$ 值を評価した結果，粒状酸化覀鉛（PFA $=2.3$ $\pm 0.3)$ ，針状酸化西鉛（PFA $=3.0 \pm 0.5 ）$ ，薄片

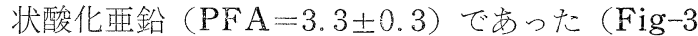
(b))。これは前者で示した吸収曲線の結果を反映 して和り，薄片状酸化亚鉛が紫外部，特にUVA 領域 (320 400nm) で他の形状と比較し相対的に 高いPFA 值を示した。

酸化チタンでは $\phi 0.05 \mathrm{~nm}$ でンリコン処理した 微粒子酸化チタンが $(\mathrm{PFA}=3.5 \pm 0.5), \phi 0.2 \mathrm{~nm}$ でンリコン処理が $(\mathrm{PFA}=2.0 \pm 0.5), \phi 0.2 \mathrm{~nm}$

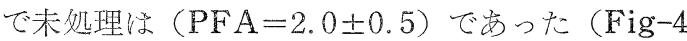
(b))。このことは散乱光の強さほ粒子径が小さい 程高い3)といらことからも防御效果には粒径も関 与することが示瑢された。

また，午れぞれのサンプルをモルモット表皮シ 一トに塗布し，300～500nm の紫外線透過率曲線 を測定した結果，微粒子酸化チタン>薄片状酸化 亜鈶>針状>粒状の順でその透過防御効果が大き く紫外線透過防御效果が PFA 值に反映されてい 万( 专ig-5)。

\section{3 薄片状酸化巠鉛配合クリームの濃度依} 存性

薄片状酸化亚鈶を0.5\% 10\% で濃度を变化 させクリームに配合LPFA 值をPUVA 社にて 評価した結果， $3 \%$ 配 合（PFA1.5 土0.3）より

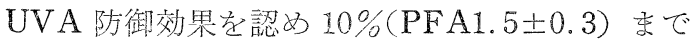

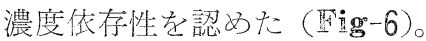

一方 $0.5 \sim 2 \%$ 配合》リーム塗布では未処理表 皮シートよりも透過度が上がり，紫外線防御効果 が PFA=1 以下と低下するが，これはクリーム により皮膚表面のスムーシングが起こるため，逆 に紫外線を透過し易くなったためと考光られる。

また，モルモット表皮シートを用いた透過率曲 線を（宜ig-7）に示す。透過防御も配合濃度を高 くするに従い大きくなり $360 \mathrm{~nm}$ 付近では $5 \%$ 配 合で 2 割， $10 \%$ 配合で 4 割の透過を防御してい る。一方 PFA 值にみら机るよらに0.5，2\%配合 では未処理の表皮シートよりも透過度が高くな

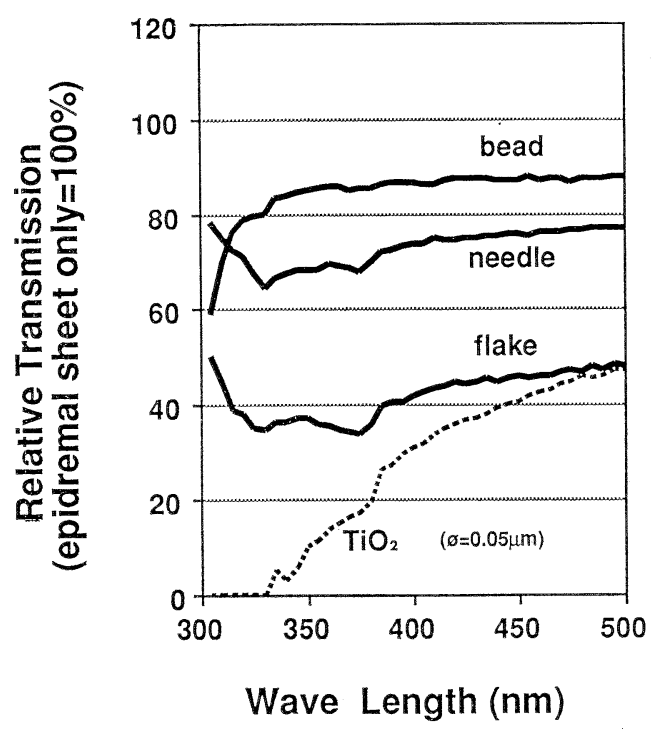

Fig. -5 Relative transmission of epidermal sheet which was painted with sample containing $7 \% \mathrm{TiO} 2(\theta=0.05 \mu \mathrm{m})$ or $7 \% \mathrm{ZnO}$ (flake-, needle- and bead-) in $\mathrm{EtOH}$.

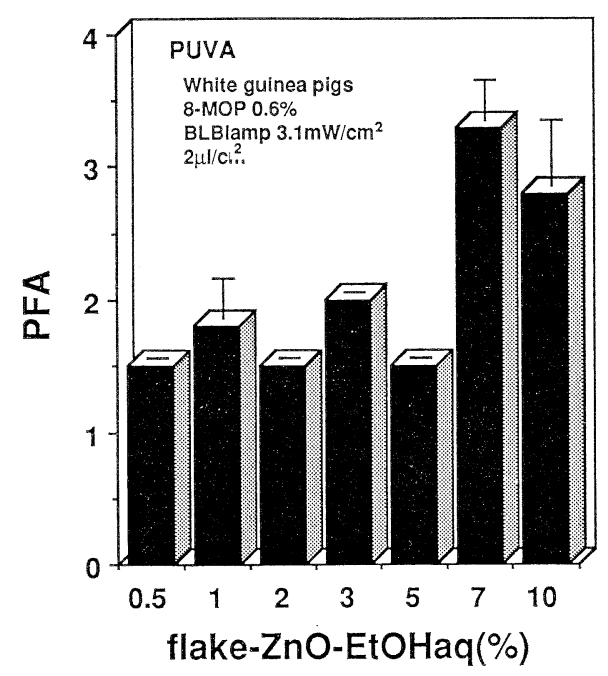

Fig.-6 Dose dependency of effect flake- $\mathrm{ZnO}$ on PUVA induced of guineapig skin.

りっクリームを塗布することで逆に紫外線を透過 し易い状況にあることが確認された。

\section{4 皮膚上での薄片状酸化亚鉛の被覆状態} 白色モルモット表皮シート上に $2 \% ， 7 \%$ 薄片 


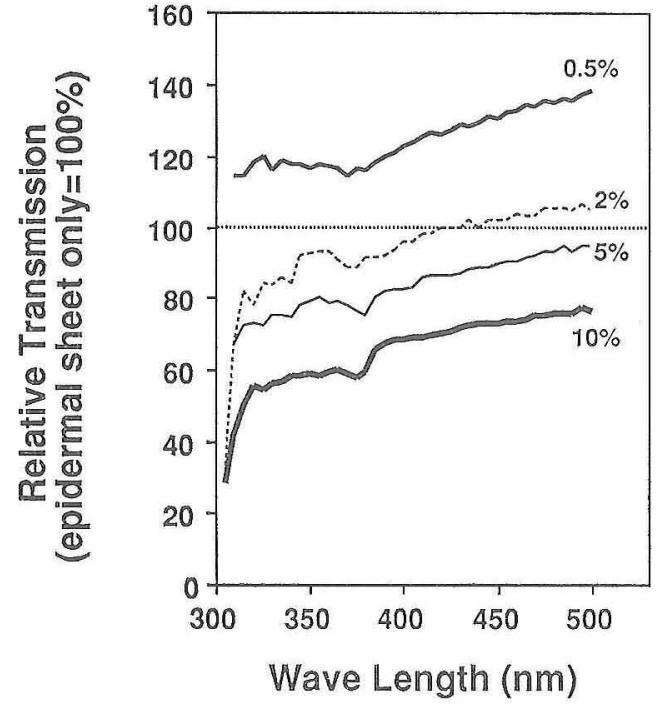

Fig.-7 Electron microscopic observation of flake- $\mathrm{ZnO}$ on back skins of guinea pigs.

状陵化亜鉛の $\mathrm{E} t \mathrm{OH}$ 分散溶液 $2 \mu \mathrm{l} / \mathrm{cm}^{2}$ 塗布し た時の被覆状態を走查型電子顕微鏡で観察した (Fig. - 8)。

その結果, EtOH 分散溶液で PFA $=3.3 \pm 0.3$ を示した $7 \%$ 濃度では皮膚表面を均一に被覆して いるが，一方 $2 \%$ 濃度で PFA=1.5土0であった 酸化亜鉛の分布には偏りがみられ，皮膚表面が被 覆されていない箇所が観察された。このことは粉 体の皮膚表面上の被覆状態と防御効果との間滵 接な関係を有し，より均一に皮膚を被覆すること が紫外線防御効果には望ましいことが示唆され た。

\section{5 薄片状酸化亚鉛配合クリームの $\mathbb{P F A}$ 值 評価}

ヒト背部での HUVA 法による黒化度を指標 としたPFA 值を評価した結果，照射終了24時間 後の即時黑化の判定では, 薄片状酸化覀鉛 $0.5 \%$

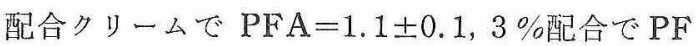
$\mathrm{A}=2.0 \pm 0.6,5 \%$ 配合クリームで $\mathrm{PFA}=2.7 \pm$ $0.3 ， 10 \%$ 配合クリームで PFA=3.0 0.3 であ った（Fig-9）。また照射終了 5 分後, 照射終了 1 時間後の黑化度を評価では，いずれも前者と同様 に配合濃度が高委るに従い防御效果多増大した。
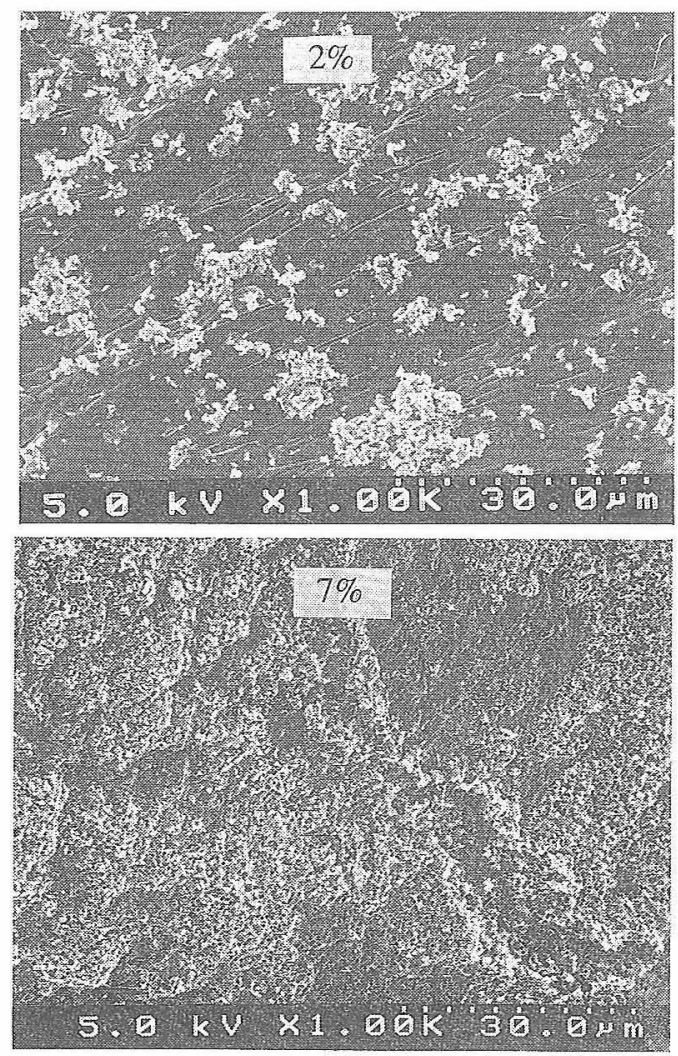

Fig. -8 Relative transmission of flake- $\mathrm{ZnO}$ painted epidermal sheet at different concentration.

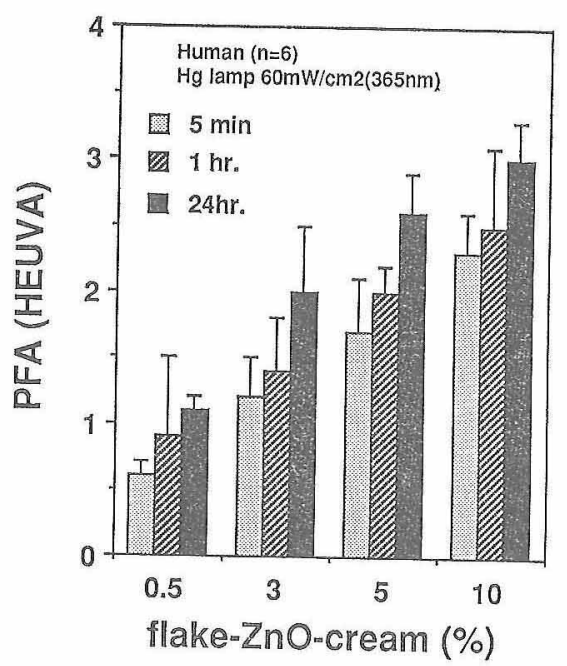

Fig.-9 Preventive effecf of flake- $\mathrm{ZnO}$ on Hg lamp induced meranogenic of human back skin. 
このことよりとトの場合, UVA の影響として即 時黒化，遅延黑化がみられるが，その防御のため には薄片状酸化覀鉛 $3 \%$ 以上の配合が必要である

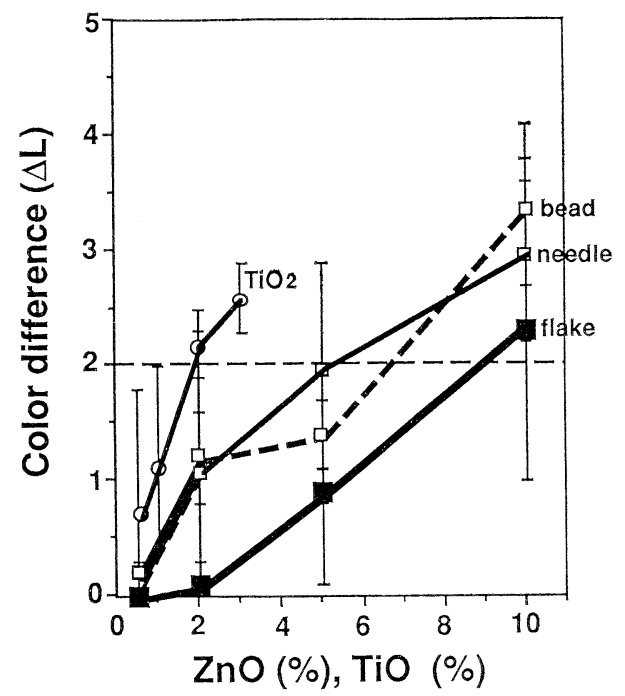

Fig. -10 Whity effect of different concentrations of $\mathrm{ZnO}$ (flake--, needle- and bead-) or $\mathrm{TiO} 2(\theta=0.05 \mu \mathrm{m}$ ( on Japaneaee ekin.

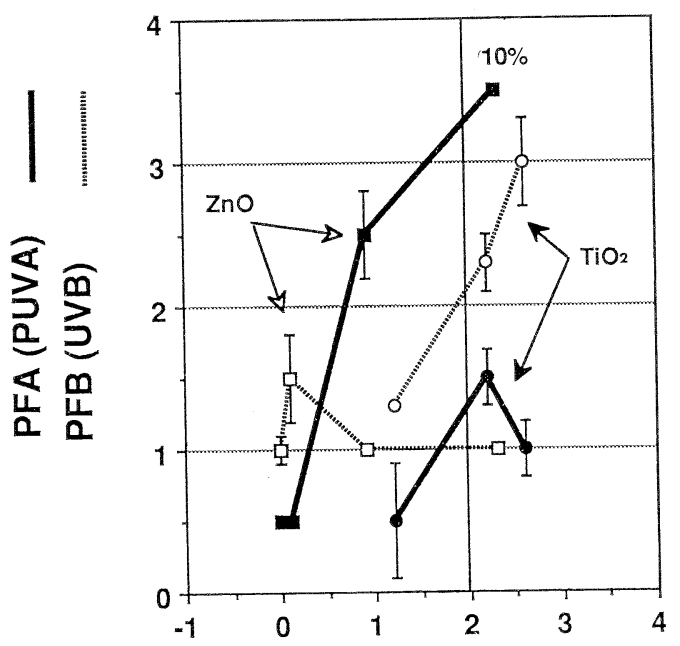

$\Delta \mathrm{L}$ (color difference)

Fig. -11 Relationship between whiteness and photoprotective ability in different concentrations of $\mathrm{ZnO}(0.5,2,5$, $10 \%)$ and $\mathrm{TiO} 2(1,2,3 \%)$.

\section{ことが示唆された。}

\section{6 紫外線防御効果と白浮き度との関係}

形状の異なる酸化亚鉛，微粒子酸化チタンは同 一配合濃度であっても, 皮膚塗布時の白色度に違 いがあり，白色度が高い場合には使用時に和いて 「白浮き」として不快感を覚える。color difference $(\Delta \mathrm{L})$ を指標とするこの評価系の場合，七 卜皮膚上（日本人， $\mathrm{n}=21$ ) に和いて， $\Delta \mathrm{L}$ 值が 2 以上のときに，使用感で「白浮き」を生じる。

そこで酸化亜鉛, 微粒子酸化チタンの配合濃度 を変化させ，その $\Delta \mathrm{L}$ を測定した結果，微粒子酸 化タンは配合濃度 $2 \%$, 粒状, 針状酸化亜鉛では $7 \%$, 薄片状酸化亚鉛では $8 \%$ 以上の場合に $\Delta \mathrm{L}$ が 2 以上となり「白浮き」を生じた $(\mathbf{F i g}-10)$ 。こ のことは用いる散乱剂の種類によって配合濃度に は限界があることが示唆された。

そこで前述した『白浮き』の点で限界となる濃 度での紫外線防御効果は，微粒子酸化チタン $2 \%$ 配合で $\mathrm{PFA}=1.5, \mathrm{PFB}-2.3$, 薄片状酸化亜鉛 7 \%配合で $\mathrm{PFA}=3, \mathrm{PFB}=1$ であった（Fig-11）。

以上のことから紫外線散乱剂を配合する場合, 紫外線防御効果だけでなく使用感とのバランスを 考慮して配合検討する必要がある。今回『白浮 き』を白度として数值化し，薄片状酸化亜鉛の配 合量との相関をみたが，この白度については透過 度の強度に比例して増加して増加し, 可視部の透 過度が低いほど透明感が高まると言われている。 実際, 酸化チタンに招いて径が $0.2 \mu \mathrm{m}$ と $0.05 \mu \mathrm{m}$ の吸収曲線をみると $400 \mathrm{~nm}$ 以上に拈いて $0.05 \mu \mathrm{m}$ が $0.2 \mu \mathrm{m}$ と比較して吸収が低く, 透過度が高く なっていた。このことは粒径のみならず形状, 表 面処理, 粉体の分散状態も関与していると考兄ら れ今後さらに技術検討が必要であると思われる。

\section{引用文献}

1）日本顔料技術協会編：改定新版，顔料便覧

2) 誠分堂新光社, p 438 (1989), 粉体工学便覧: 粉 体工学編, p 927 (1986)

3）公開特許公報 $(・ 1-175921)$

4）公開特許公報 $(\cdot 1-230431)$

5) Gange RW, Blackett AD, and et al. : Compatative Protection efficiency of UVA- and 
UVB-induced tans against edythema and formation of endonuclease-sensitive sites in DNA by UVB in human skin., J. INVEST DERMATOL, 85 : p362 (1895)

6) Imokawa G., Tejima T., Kirii M., and Kawai M.: Efficacy of 4-methoxy-sunscreen.,
J. Soc. Cosmet. Chem., 41 : 67-84 (1990)

7) Elaine T.Kaye, Jay A.Levin H., and et al. : Efficiency of Opaque Photoprotective Agents in VisibleLight Range, Arch Dermatol, 127: 351-355 (1982)

(1992年10月 6 日受理) 